\title{
The Implication of Tax Amnesty Policy on The Increase of State Revenue from Tax Sector
}

\author{
Budi Ispriyarso \\ \{budiispriyarso@ymail.com\} \\ Diponegoro University, Jl.Prof.H.Soedarto, S.H., Tembalang, Tembalang, Kota Semarang, Jawa Tengah \\ 50275 Indonesia
}

\begin{abstract}
The Government of Indonesia has made a policy in taxation known as Tax Amnesty. The tax amnesty is a forgiveness taxation program granted by the Government to the taxpayer to cover the abolition of taxes that should be owed, the removal of tax administration sanctions, and the elimination of criminal penalties in taxation, by paying the ransom. The existence of tax forgiveness policy is based on economic considerations to obtain funds for the financing of government programs. Should the tax amnesty is proven rewarding, is the aim of this article to achieve. The research method used in this research is juridical empirical. The result of this research is that the implementation of tax amnesty policy in Indonesia has not been as expected, i.e., the target of tax revenue from tax amnesty is not achieved. This is because there are still many taxpayers who have not followed the tax amnesty activities. The tax amnesty policy should be followed by other procedures such as firmer law enforcement and refinement of the Law on General Provisions and Tax Procedures, the Law on Income Tax, the Law on Value Added Tax on Goods and Services and Sales Tax on Luxury Goods, as well as other strategic policies in taxation and banking so as to reduce non-compliance of taxpayers in the future through a secure database generated by the implementation of this act.
\end{abstract}

Keywords: Tax Amnesty, Taxation Policy, State Revenue

\section{Introduction}

Various economic problems faced by the Indonesian government, i.e., slow economic growth, poverty, unemployment, rising of inflation, foreign debt, corruption, rising food prices, and so forth. Being faced with such conditions, the government should pursue all existing potential revenues. This is in line with Bebbington et al., stated that about economy problem[1]. Currently, several potentials have been explored to increase state revenue, both domestic and foreign. Until recently, the revenue from the tax sector remains the government's primary revenue source. Nearly $80 \%$ of state revenue is sustained by taxation sector. Even the tax revenue target has been increased each year.[2].

Tax is a levy by the state to the people based on the law. There is no direct contraachievement that may be designated and used for financing the state expenditures.

One of the government policies in order to increase revenues some times ago (i.e., 2016) was a tax amnesty policy known as "Tax Forgiveness." The Government issued Law No. 11 of 2016 on Tax Forgiveness. Tax amnesty should be applied under the law, which means that it must involve two parties, namely the president and the House of Representatives[3]. Tax amnesty is the elimination of tax owed, should not be sanctioned tax administration and criminal sanctions in the area of taxation by disclosing the property and paying the ransom[4].

For many countries, the forgiveness of tax (tax amnesty) is often used as an instrument to raise state revenue from the tax sector (tax revenue) quickly in a relatively short period. The tax amnesty program was implemented because of a considerable proportion of tax 
evasion[5s]. In fact, in the period 1989-2009, nearly 40 states in the United States had provided tax amnesty in various forms.

Concerning the forgiveness of tax (tax amnesty), it is never apart from underground economic problems (underground economy)because the underground economy is part of the economic activity deliberately concealed to avoid payment of taxes. Underground economic activities generally take place in all countries, both developed and developing countries.

Under Law No. 11 of 2016, it is determined that the tax amnesty is carried out within three periods since its issuance on March 31, 2017

Today, the tax amnesty had been completed. It is undoubtedly exciting to examine the implementation of oft he tax amnesty. Has the tax amnesty brought the expected results or not? Did many taxpayers follow the tax amnesty or vice versa many taxpayers were reluctant to follow the tax amnesty program? How about the repatriation of property, ransom, and so forth? The problems were: 1) How the implementation of the Tax Amnesty policy in Indonesia, 2) How the implication of the Tax Amnesty policy to the state revenue, the repatriation, and the next steps taking by the government to follow up the Tax Amnesty? Due to the problems, the aims of the study were: 1) to observe and to analyze in detail the implementation of the tax amnesty by the Indonesian government some times ago (2016 -2017), 2) to determine and to analyze the tax amnesty policy implications particularly on its success in achieving the planned goals including the increase in tax revenue (including further actions after the tax amnesty). The results of the study are expected to be useful for the government, especially in making taxation policy in the future. Andreoni argued that there are two main concerns about tax amnesty. First, if it is anticipated, it may increase cheating and reduce the efficiency of the tax system. Second, amnesty may be inequitable by letting cheaters "off the hook" [6].

\section{Methodology}

The study used an empirical juridical approach which is a study that examines how the execution or implementation of positive law (legislation) and contract factually on any particular legal events that occur in the community in order to achieve predetermined objectives[7]. In relation with empirical juridical research method, the main data sources were primary data (obtained directly from the field/ community). In this case, it was on how the application of the tax amnesty, in particular, Law No. 11 of 2016, on Tax Forgiveness in Indonesia.

The secondary data derived from library study included official documents, books, journal, research results in the form of research reports, and so forth. The primary data were obtained from field research by interviewing the parties related to the tax amnesty policy (in this case, the Directorate General of Tax or official duties/ authorities related to the implementation of the tax amnesty).

\section{Findings}

The state is a public institution with the government that owns powers for political support of all citizens so that it has the sovereignty and dignity as anindependentcountry[2].

The goal of the state is organizing a good life for all citizens. In a welfare state, the main goal is to achieve the welfare of society. The success of the country in achieving that goal depends on the strategies and techniques in collecting funds from the public. Likewise, to the Indonesian government, the success in achieving the goals of the country highly depends on the funds that support the financing of the objectives. 
The goals of the Unitary State of the Republic of Indonesia (NKRI) are stated in the Preamble of the 1945 Constitution, in the fourth paragraph; "Later, to form a the government of the state of Indonesia, to protect the entire Indonesian nation and the entire homeland of Indonesia, and to promote the general welfare, to educate the nation, and to participate in the establishment of world order based on freedom, lasting peace and social justice ... ".

Based on the formulation, it implies the national/ state goals to be achieved and, at once, a task that must be implemented by the State, i.e.:

a. to protect the entire Indonesian nation and the country of Indonesia;

b. to promote the general welfare;

c. to enrich the life of a nation;

d. to participate in the establishment of the world order based on freedom, lasting peace, and social justice.

About the achievement of the objectives, the Indonesian government continually finds ways to increase state revenue from various sources.

According to Law No. 17 of 2003 on State Finance, the state revenues and grants are all state revenues derived from tax revenues, non-tax revenues, and the receipt of domestic and foreign grants.

- The revenue of taxation is any revenue consisting of domestic taxes and international trade taxes. Domestic taxes are all state revenue coming from income tax; value-added tax for goods and services, sales tax on luxury goods, building and land taxes, acquisition duty of land and buildings, excise and other taxes. International trade taxes are all state revenue from import duties and export taxes/ levies. Thus far, the structure of state income is still dominated by tax revenue, mainly domestic tax revenue from non-oil sectors.

- The state revenue of non-tax are all revenues received by the state in the form of revenues from natural resources, the government's share in the profits of state-owned enterprises, other non-tax revenue. As one source of revenue, non-tax revenues play an essential role in supporting the needs of funding budget in the state budget, although it is very susceptible to the development of various external factors. Non-tax revenues are also affected by the changes in macro-economic indicators, particularly the exchange rate and the price of crude oil in the international market. It is mainly due to the structure of non-tax revenues which is still dominated by the revenue of natural resources (SDA), particularly from the revenue of petroleum and natural gas (fuel), which are strongly influenced by the development of the exchange rate, the price of crude oil, and oil lifting level.

- The revenue of grant is all state revenue from private donations as well as donations of the domestic private sector and foreign governments. Grant revenue which is recorded in the state budget is contribution or donations (grants) from foreign countries, national agencies, and individuals with no obligation to pay back. The development of state revenues derived from the grant in each budget year depends on the commitment and willingness of donor agencies to donate (aid) to the Government of Indonesia.

As mentioned above, tax is a source of state revenues. Tax is a significant source of state revenue, in addition to other sources of income (the state's non-tax revenue, grant, etc.).

In general, the definition of tax is the contribution of taxpayers to the state that is enforceable under the laws used for state's need for the greatest prosperity for the people given the economic aspect; tax is defined as the shift of resources from private to the public sectors. Notably, in terms of legal aspects, as proposed by Rochmat Soemitro, tax is an engagement that arises due to coercive laws, contra-achievement directly designated that requires a person or entity that meets the requirements set by law to pay a certain amount of money and used for the financing confident state administration. 
The tax has two functions: regular and budgetary functions. The regular function has a definition that taxes can be used as an instrument to achieve specific goals. For example, when the government intends to protect the interests of domestic farmers, the government may set additional taxes, such as import taxes or customs duties on imports of certain commodities.

Budgetaryfunctionreferringto, as the primary function of tax or fiscal (fiscal function), is a function in which tax is used as an instrument to input funds optimally to the state treasury using tax laws and regulations. The function is called primary function for the function is which historically first raised. Here, tax is the most significant source of state financing. By the primary function of tax which is the function of budgetary/ financial functions, tax plays a vital role in the state revenue. Tax is a significant source of state revenue. Its role, over the years after tax reform in Indonesia, continues to increase.

The State Revenue Target in the National Budget of 2016 was set at IDR.822,5 trillion or IDR 25.6 trillion lower than the Draft of the National Budget proposed in 2016. The target of the Draft of the National Budget was sourced from the State Revenue of Tax of IDR 1,546,7 trillion and the State Revenues of Non-Tax IDR 273,8 trillion (the ratio of state revenue to GDP or tax ratio in 2016 by 13.11 percent).

\subsection{Implementation of Tax Amnesty in Indonesia}

Tax amnesty program has been performed in many countries around the world, both developed and developing countries with success and failure stories. India (1997), Ireland (1988), and Italy (1982, 1984, and 2001/2002) are examples of the countries successfully held tax amnesty programs. Meanwhile, Argentina (1987) and France (1982 and 1986) are examples of the failed states in managing tax amnesty programs.

However, it is undeniable that tax amnesty is a controversial issue in the world of taxation. The underlying assumption of the disputed tax amnesty is the abolition of tax principal, administrative sanctions, an / or tax punishments for non-compliance taxpayers in the past to improve compliance in the future. On the one hand, tax amnesty is seen as a way to increase revenues in the future since tax amnesty provides an opportunity for taxpayers to enter or return to the tax administration system which increases revenue in the future. However, on the other hand, tax amnesty can reduce the level of compliance in the future if taxpayers retain their disobedience after tax amnesty ends with the hope of tax amnesty in the future.Torgler\&Schaltegger stated that honest taxpayers might feel upset by an amnesty. If most taxpayers voluntarily comply with tax laws [8].

In 2016, Indonesia issued a policy on Tax Amnesty. The implementation of the tax amnesty in Indonesia was performed by issuing Law No. 11 of 2016 on Tax Forgiveness (ratified on March 31, 2016). The law, later in its development, comes with its implementing regulations, i.e.:

- Minister of Finance Regulation No. 118 / PMK 03/2016 on the Implementation of Law No.11 of 2016 on Tax Forgiveness.

- Minister of Finance Regulation No. 119 / PMK.03 / 2016 on the Stipulation of Bank

Perception acting as the ransom receiver for the implementation of Tax Forgiveness

- The Regulation of the Director-General of Tax No. PER-07 / PJ / 2016

- The Publication Letter of the Director-General of Tax No. SE -30 / PJ / 2016

Before the tax amnesty policy was implemented in Indonesia, it had been socialized to the public through mass media and the outreach by the Tax Offices. It was expected that, with the socialization, people could understand the provisions regarding tax amnesty. However, some people thought that the socialization time was too short, so some of them suggested that the application of the tax amnesty should be postponed. On the other hand, the government 
continued to apply the tax amnesty by the provisions of Law No. 11 of 2016 from the time when it was enacted to the end of March 2017.

Based on the reality on the field, it was found that the tax amnesty was most widely followed by the taxpayers in the first period, while the second period had fewer participants and it was much scarcer in the third period. It occurred since the ransom to be paid by the taxpayers in the first period was lower than the second and third periods. :

According to the statistics of the Directorate General of Tax at the website of https://pajak.go.id/statistik-amnesty, the first tax amnesty period until the last day, Friday (09/30/2016) could gain the total fund of the citizens taken back to Indonesia (repatriation) that reached IDR 137 trillion, while the total incoming ransoms reached IDR 97.2 trillion, or $50 \%$ of the target of 165 billion by March 31, 2017.

The details of the incoming funds of the tax amnesty in the first period were as follows:

Based on the incoming statement of assets (SPH) at 24.00, Friday (23/09/2016), the declaration of assets reached IDR 3,620 trillion.

In detailed, the declaration of treasures in the country reached IDR 2,532 trillion, while the statement of overseas assets reached IDR 951 trillion. Then, the repatriation reached 137 trillion.

For the total ransoms, based on the SPH received by the Directorate General of Taxa, it reached IDR 89.1 trillion. The majority of the payments came from the private taxpayers (WP) of non-SMEs.

In detail, the ransoms of the individual taxpayers of non-SMEs reached IDR 76.6 trillion, and the payments of the institutional taxpayers of non-SMEs reached IDR 9.7 trillion.

Next, the ransom of the individual taxpayers of SMEs was IDR 2.63 trillion, and the institutional taxpayers of SMEs were Rp 180 billion. Then, the realization of the ransom money that had been paid to the banks based on the Tax Payment (SSP) reached IDR 97.2 trillion.

\subsection{The implication of Tax Amnesty on the Application of State Finance}

The implications of tax amnesty policy in Indonesia resulted in positive and negative things. The negative result of the application of the tax amnesty can lead to injustice. This injustice felt by the people who have been dutifully paying taxes. They felt unfairly treated because the taxpayers who were not/less adherent got a much lower rate tax amnesty than of tax of the obedient taxpayers.

It is commonly known that the taxpayers who participated in tax amnesty gained some facilities as follows:

1. Elimination of withholding taxes with the tax assessment that had not been issued. They got no tax administration sanction and were not subject to criminal taxation sentence for the tax obligations in a tax period, part of the tax year, and the tax year up to the end of the last tax year.

2. Elimination of tax administration sanction in the form of interest or penalty, for the tax obligations in tax period, part of tax year, and tax year, up to the end of the last tax year, "Article 23 of the Regulation of the Minister of Finance (PMK) No. 118 / PMK.03 / 2016 on the Implementation of Law No. 11 of 2016 on Tax Forgiveness, as quoted from the site of kemenkeu.go. Id, Tuesday (19/07/2016).

3. No ownerships of tax audits, preliminary evidence examination, investigation of a tax crime, for the tax obligation in the tax period, part of the tax year, and the tax year, until the end of the last tax year.

4. Termination of tax audits, preliminary evidence examination, and investigation of a tax 
crime, in which the taxpayer is undergoing a tax audit, examination of preliminary evidence, and criminal investigations of tax for the tax obligations until the end of the tax year-end.

The presence of the facilities in tax forgiveness, as mentioned above, is an injustice because there is special treatment for non-compliant taxpayers who were even forgiven for not paying the tax debt, the administration sanctions, criminal sanctions for their taxes, and so forth, after paying the ransom.

It is not following the legal system that all citizens are equal before the law. Any citizen (who is qualified as a taxpayer) must pay taxes by the applicable regulations. The Law of Tax Forgiveness even gave mercy to the taxpayers who did not pay taxes. The policy was an incentive for non-compliant taxpayers, people, and companies that did not comply to pay taxes, the tax manipulators, companies and people who committed tax fraud, foreign companies that took away taxes abroad through transfer pricing. It "hurts" the sense of justice of the taxpayers who have been dutifully paying taxes by the provisions of the law (the rate of which is undoubtedly higher than the ransom).

Also, the negative result of the implementation of tax amnesty policy in Indonesian was the tax amnesty policy is contrary to law enforcement, particularly tax law enforcement. It is commonly known that the year 2016 was the year of tax law enforcement launched by the Directorate General of Taxation. The year of 2016 was the year of law enforcement as a continued effort over the program in 2015 which was the year of tax coaching by providing the opportunity for taxpayers to report and correct any tax obligations truthfully. The year of 2016 as the year of law enforcement required the Directorate General of Tax to intensify law enforcement and inspection activities as the tax investigation step to pursue the tax liabilities which were not or had not been reported by the taxpayers and took any legal action either in tax administration law or criminal law when a crime of tax was found.

Based on the campaign of the year of enforcement in 2016 by the Directorate General of Tax, the tax amnesty program did not comply with it. The tax amnesty program was not by the principles of law enforcement.

However, although there may be a risk of a negative result, the government continued to apply the tax amnesty policy. The reason was that the policy was a breakthrough (innovative) to increase tax revenues without increasing the burden of new taxes to the public. With the policy, it allows the state to take back the lost or unpaid tax. Furthermore, the taxpayers who were less/ non-compliance could be monitored because they had already been registered in the system of tax administration.

The application of tax amnesty policy, from economic aspects, was expected to increase state revenue from the tax sector and could further improve the subject and object of taxation. Tax revenue will be higher, mainly coming from the funds which were "parked" overseas. The funding increase is expected to lift the national economysignificantly through the development of financing in different productive sectors.

The research results show that, from the application of the tax amnesty, the state revenue from the tax sector increased. According to the Director-General of Tax, the revenues from the tax amnesty reached IDR 135 trillion. It consisted of the ransom of IDR 114 trillion, the payment of preliminary evidence of IDR 1.75 trillion, and the payment of unpaid tax of IDR 18.6 trillion. The total ransom consisted of IDR 91.1 trillion from the private person of nonSMEs and IDR 7.73 trillion from the private persons of SMEs. Then, the ransom from the institutions of non-SME was IDR 14.6 trillion, and IDR 656 billion from the SME institutions. The number of taxpayers who participated in the tax amnesty was 956,000 people. The tax amnesty in terms of the declaration was successful for it exceeded the target of IDR 4,000 
trillion, but the repatriation was considered a failure because it only reached less than $15 \%$ of the target of IDR 1,000 trillion.

\section{Conclusion}

Based on the information above, it can be concluded that:

1. The law had conducted the implementation of the tax amnesty in Indonesia based on Law No. 11 of 2016;

2. The tax amnesty policy in Indonesia, from the repatriation aspect, did not work because it did not achieve the expected target. The implications of the tax amnesty policy were the increased tax revenue from the ransom, the repair of the tax database (which was expected to increase tax revenues in the future). On the other hand, the tax amnesty caused injustice, particularly for the taxpayers who have been compliant so far.

\section{References}

[1] A. Bebbington, L. Dharmawan, E. Fahmi, and S. Guggenheim, "Local Capacity, Village Governance, and the Political Economy of Rural Development in Indonesia," World Dev., 2006.

[2] S. Anggara, Administrasi Keuangan Negara. Bandung: Pustaka Setia, 2016.

[3] M. Saidi, Tax Law Reform. Jakarta: Raja Grafindo Persada, 2007.

[4] N. W. Sakti, Tax Amnesty Itu Mudah. Yogyakarta: Visimedia, 2016.

[5] U. Santoso and J. M. Setiawan, "TAX AMNESTY DAN PELAKSANAANNYA DI BEBERAPA NEGARA: Perspektif Bagi Pebisnis Indonesia,” Sosiohumaniora, vol. 11, no. 2, p. 111, 2009.

[6] J. Andreoni, “The Desirability of a Permanent Tax Amnesty," J. Public Econ., vol. 45, pp. 143-159, 1991.

[7] A. K. Muhammad, Law and LegalResearch. Bandung: Citra Aditya Bakti, 2004.

[8] B. Torgler and C. A. Schaltegger, "Tax amnesties and political participation," Public Financ. Rev., vol. 33, no. 3, pp. 403-431, 2005. 